\title{
PRESUPPOSITION AND ENTAILMENT USED IN GRETA THUNBERG'S SPEECH AT UN CLIMATE ACTION SUMMIT 2019
}

\author{
${ }^{a}$ Nurul Aini, ${ }^{b}$ Lisetyo Ariyanti \\ ${ }^{a, b}$ Sastra Inggris - Fakultas Bahasa dan Seni (Universitas Negeri Surabaya) \\ e-mail: lisetyoariyanti@unesa.ac.id
}

\begin{abstract}
Climate change is one of the hottest topics lately. Global emissions are reaching record levels and showing no sign of peaking. Antonio Guterres UN Secretary-General invited all leaders to join Climate Action Summit in New York, 23rd September 2019. This summit also featured the participation of business leaders, indigenous people, youth, and many others. The star of the showed Greta Thunberg a Swedish teen activist who sailed to New York for the event from Sweden on a zero-emissions sailboat. This research aimed to reveal how presupposition and entailment were used in the speech and how they were contributing to the context of the speech. The research used a descriptive qualitative method for analyzing her speech which involved document and material analysis to collect the data. The results showed that this research found out that the most commonly used presupposition is existential presupposition. The function is to emphasize, to draw attention and sympathy toward the listeners. While the most used entailment is one-way entailment. This type of entailment is commonly used to deliver the ideas through the utterance by adding some more details of the main idea. Existential presupposition and one-way entailment led to the referential function of language which aimed to send information or the speaker's idea to the audience. It can be concluded that the presuppositions of the speech must be entailed by the global context, which means the global context or common ground knowledge entails that presupposition. In a word, both presupposition and entailment hence become a strategy to make the audience become more focused in the context of the speech.
\end{abstract}

Keywords: Presupposition, Entailment, Speech 


\section{INTRODUCTION}

Public speech is an activity that is usually done by important figures such as, leaders, politicians, motivators, activists, and many others. Public speech has many functions which depends on the purpose the speaker is trying to achieve with their speech. As an activist, speech has become one of the many ways to get people to listen to their message. Among many activists around the world, there is a person who stands out who is very young, her name is Greta Thunberg. She is a 16-years-old Swedish environmental activist on climate change who becomes one of the hottest topics of the year. At the age of 15, she began spending her school days outside of the Swedish Parliament, demanding stronger action against global warming by holding a sign saying "School Strike for the Climate". Her speech at U.N Climate Action Summit 2019 in New York made her fame rose up. She addressed the world leaders to take strong action against climate change. Thunberg told a lot of statements, like expressing how she felt about climate change, facts about climate change, and many more. Greta Thunberg's way of speaking is forceful and she backed up her arguments with wellchosen scientific data points which appeared to be in contrast with the style of her peers. Her speech contains some presupposition and entailment.

A presupposition is when something presupposed to be true in a sentence that contains other information. It is also required how the speakers organize what they want to say in accordance with whom they referring to, where and when they are talking, and in what circumstance they are talking. All types of presuppositions convey meaning more than what is said. The use of presupposition can be analyzed by using a theory that connects the production and comprehension of speech act. The presupposition theory has been defined by many scholars and researchers, which often is almost similar or identical to each other. George Yule (1996:25) is one of the linguists who explained that presupposition is something the speaker assumes to be the case prior to making an utterance. He also divided presupposition into six types. The Presupposition that appeared in Greta Thunberg's speech appears in many different types. Meanwhile, entailment is a logical concept related to the meaning of one sentence to the others. It is important to understand the relation between sentences. When a sentence is related to other sentences, the idea in the sentences becomes stronger. As stated by Griffith (2006: 25) entailment happens when the truth of one proposition depends on each other, it means that the truth of two propositions correlates with each other. In order to find the connection between presupposition, entailment, and the context of the speech, the research was analyzed by dynamic approach theory by Stalnaker $(1970,1973,1974,1978)$ and language function by Roman Jakobson (1960) and Holmes (2001).

There are several research in the past that have analyzed speeches before. One of them (Ariyanti \& Nistiti, 2019) Maintaining Confessional Discourse through Presupposition in Feminist Speech. In their research, they analyzed the types of utterance in a speech by Chimamanda Ngozi Adichie. The result of their research is that Chimamanda Ngozi used three confessional discourse function which are, therapeutic, interrogatory and didactic through presupposition types.

Another research was done by Ida Catur Wahyu (2016), with the title Revealing the Function of Reference in Presupposition of English Cigarette Taglines. In her research, Ida analyzed the tagline using presupposition and referring expression by Yule (1997). She found that existential presupposition is mostly used in the advertisement to maintain the product existence by employing conciseness and emphasis function. Meanwhile, the use of referring expression helps to limit the 
consumers' inference of the presupposition information. There are three referring expressions that are found, which are proper nouns, noun phrases, and pronouns.

This research attempts to analyze what types of presupposition and entailment that used in Greta Thunberg's speech and what is the contribution of presupposition and entailment in the speech. And the goal of this research is to define the relation between the presupposition and entailment types and revealing the contribution of presupposition and entailment in Greta Thunberg's speech.

\section{Presupposition}

The general definition of Presupposition is the relation between sentences or propositions (with interpretations), either belonging to semantics or to pragmatics. As stated by Richardson (2007), Presupposition refers to the information triggered by certain linguistic construction which is irrefutably credited as absolute truth by participants in an utterance in a specific context. Yule (1996:25) explained that presupposition is something the speaker assumes to be the case prior to making an utterance. In this case, the speaker has presupposition in the form of utterances, not sentences. According to Yule (1996:27), presupposition can be found in linguistic form as indicators of potential presupposition, which can only become actual presuppositions in context with speakers. Yule divided presupposition into six types. Existential presupposition is the assumption assumed to be committed to the existence of entities named by the speaker and present in possessive construction such as 'my cat' which leads to a particular strong presupposition about the existence. Factive presupposition is the assumption that something is true and it is identified by the presence of some verbs such as know, realize, regret, aware, glad, be and etc. The use of these verbs triggers the presupposition that what follows is a fact. Lexical presupposition is the assumption that is using one form, the speaker can act as if another meaning will be understood. Structural presupposition is the assumption from a certain sentence structure where the information presented in the sentence is already considered as the truth. (Yule, 1996). The part of the sentence structure contains words and phrases. The speaker can use such structures to treat information as presupposed and accepted it to be true by the listener. It can easily found in the use of 'WHquestion' construction in English. Non-factive presupposition is the assumption that is assumed to be untrue. It can be identified by words like imagine, pretend, dream, etc. The use of those words triggers the presupposition that what follows is fiction. Counterfactual presupposition is the assumption that what is presupposed is not only untrue but also the opposite of what is true, in other name is contrary to the fact. Identified by the words IF-clauses.

\section{Entailment}

As stated by Griffiths (2006:25), entailments can be described as a proposition that is definitely true when given a proposition. Yule (1998:129) also stated that entailment is something that follows from what is mentioned before. In addition, Rambaud (2012:70) stated that entailments are related to the knowledge of a particular language, and not the knowledge of the truth and falsity of the normal sense of the world. It was concluded that entailment is sentential meaning relation (Fromkin, Rodman and Hyams, 2003:195) Entailment can be divided into several types. According to Griffiths (2006), there are two types of entailment, they are one-way entailment and two-way entailment. According to Brinton (2000:13), one-way entailment is different from paraphrase. In one-way entailment, a sentence does not 
paraphrase the other sentence. One of them similar to the conclusion of the other. It is an entailment that works only in one direction. Kreindler (1998:86) provides the illustration of this entailment. When the two propositions are labeled as ' $p$ ' and ' $q$ '. If ' $p$ ' is true, ' $q$ ' must be true. But if ' $q$ ' true, it does not necessarily that ' $p$ ' also true since it can be false. For example, if the sentence My shirt is navy is true, then the sentence My shirt is blue is true. But, if the sentence My shirt is blue is true, then the sentence My shirt is navy is not always true. As stated by Griffiths (2006:27), in contrast with one-way entailment, two-way entailment has a meaning which correlates to each other, and the sentences that contain two-way entailment paraphrase each other. Fromkin, Rodman, and Hymans (2003:197) stated that two-way entailment or paraphrase is sometimes expressed in the term of active-passive pairs. For example, the sentence She did not invite me to the party and I was not invited to the party is in relation to two-way entailment or paraphrase.

\section{Dynamic Approaches}

Based on the theory by Stalnaker $(1970,1973,1974,1978)$ presuppositions are generally seen as imposing requirements on the possible context of utterance. In his theory, this is the fundamental pragmatic ideas. Based on the idea of contexts of utterance in terms of the common ground - the set of worlds which compatible and mutually supposed for purpose communication. Assertation used to add information to the common ground. On the other hand, presuppositions fit well with what is already entailed by the common ground, This shows that presuppositions are an aspect of meaning that is taken for granted by the participants. An utterance that comes with a presupposition requires the common ground entail the presupposition in order to be precise.

\section{Language Function}

According to Roman Jakobson (1960), there are six functions of language (or communicative functions). Each of the functions has an associated factor. They are the referential, the emotive/expressive, the conative/directive, the poetic, the phatic, and the metalingual function. Based on Holmes (2001) the referential function is a function to convey information it can be seen through different forms of speech such as interrogative or declarative speech. This function is oriented towards the context of communication. The referential function aims to send information or to tell others about the speaker's idea. According to Jakobson (1960), this function is the function towards the message as such, focus on the message for its own sake. This function is oriented towards the message of communication and focuses on the paradigmatic and syntagmatic category reversal. The poetic function is aimed at foregrounding textual features in a particular form is the essence of the message. Based on Jakobson (1960) emotive function is focused on the addresser, aims at a direct expression of the speaker's attitude toward the speech, and is oriented to the speaker. The function of this function is to communicate the emotion of the speaker or expressing the feeling of the speaker. The conative function is oriented toward the speaker. It occurs earliest in the child's language acquisition. This function is influencing behaviour towards other words. Through this function, the speaker aims to get someone to do something related to the speaker's utterance.

Based on Lanigan (2010) the phatic function is focused on physical and psychological engagement. This function also distinguishes the first and the second person discourse function. According to Jakobson (2007), the phatic function has a 
function as the opening, checking that is working or not as the representation of the social relationship. This function is oriented on the contact between the speaker and the receiver. According to Jakobson (1960), the metalingual function is that whenever the speaker or the audience needs to check whether they use the same code, speech is focused on the code: it performs a multilingual function. This function is aimed to refer to the natural interaction and focusing upon the code, whether clarify it or renegotiate it.

\section{METHOD}

The writer used qualitative approach after considering the nature of the data and the objectives of this research. This method employs deep analysis via detailed description rather than using number in analyzing data such as in quantitative method. The analysis explained the presupposition and entailment that used by Greta Thunberg in her speech. By using descriptive method, it was easier to find the variant and the meaning of presupposition and entailment which included in Greta Thunberg's speech. This research also explained the function of presupposition and entailment that are used in the speech. The subject in this research is Greta Thunberg. The data in this research are utterances which used by Greta Thunberg in her speech at U.N Climate Action Summit 2019. This research used a presupposition and entailment analysis based on George Yule's presupposition theory and entailment theory by Griffiths (2016). The source of data was taken from www.npr.org. Data collecting technique in this research applying documentation technique. The writer retrieved the script of the speech from www.npr.org. Therefore, the data is collected from the utterance of Greta Thunberg's speech. In answering each research question, the writer uses different elements related to the problem applied. After the data are collected, it performed data reduction, whereas data which considered unimportant for research had been eliminated and the researcher will only focus to data which related with the research. To answer the research questions, this research analyzed the presupposition and entailment that used in the speech. From the result, the research questions may be answered by find out what type of presupposition and entailment used in speech and what is the contribution to the topic of the speech. After that drawing the conclusion and giving suggestion based on the result of the analysis.

\section{FINDINGS AND DISCUSSION}

\section{Findings}

The finding shows six types of presupposition with further description of presupposition in the first paragraph. The finding also shows two types of entailment used in the speech, and the language function which found in the speech.

\section{Presupposition}

After analyzing the utterances contained on Thunbergs speech, this research found that there are five types of presupposition, and two types of entailment that used by the speaker. They are existential presupposition, counterfactual presupposition, factive presupposition, non-factive presupposition, and lexical presupposition. The researcher did not find any structural presupposition. And one-way entailment and two-way entailment. The speaker preferred to apply existential presupposition and one-way entailment in her speech. Existential presupposition used to emphasize, 
drawing attention and sympathy from the audience. While, one-way entailment is the most common used entailment in delivering idea.

\section{a. Existential Presupposition}

Utterance: "You have stolen my dreams and my childhood with your empty words and yet I'm one of the lucky ones". Based on Yule (1996), existential presupposition present in possessive contraction. The word my and your is categorized as possessive contraction because it is possessive adjectives. The word "my" refers to herself or the speaker, and the word "your" refers to the audience or the world's leaders that attended the summit.

Utterance: "The popular idea of cutting our emissions in half in 10 years only gives us a 50 percent chance of staying below 1.5 degrees and the risk of setting of irreversible chain reactions beyond human control".

This sentence is triggered by possessive pronoun, as can be seen in the utterance above by the word "our". The word "our" refers to the speaker and the audience. Also, the use of definite noun phrase "the popular idea" which the speaker assumes that the popular idea is exist and it makes this sentence categorized as existential presupposition.

\section{b. Counterfactual Presupposition}

Utterance: "This is all wrong. I shouldn't be up here. I should be back in school on the other side of the ocean.

Based on Yule's theory counter-factual presupposition has a meaning that what is presupposed not only true but it is the opposite of what true (contrary to facts). The sentence "I shouldn't be up here. I should be back in school" was contrary to the facts that she is attending the summit.

Utterance: "You say you hear us and that you understand the urgency, but no matter how sad and angry I am, I do not want to believe that. Because if you really understood the situation and still kept on failing to act then you would be evil and that I refuse to believe"

According to Yule, the characteristic of counterfactual presupposition is identified by the words IF-clauses.

In this utterance it shows that even the world leader understands about the situation but they keep failing to solve the problem.

\section{c. Factive Presupposition}

Utterance: "To have a 67 percent chance of staying below 1,5-degree global temperature rise - the best odds given by the IPCC (Intergovernmental Panel on Climate Change). The world had 420 gigatons of CO2 left to emit back on January 1st 2018. Today, that figure is already down to less than 350 gigabytes"

The sentence above is categorized as factive presupposition because triggered by the word "odds". The use of this word indicate what follows is facts. 
Utterance: "There will not be any solutions or plans presented in line with these figures here today, because these numbers are too uncomfortable and you are still not mature enough to tell it like it is."

The types of factive presupposition use verbs or words that refer to reality or facts (something true). In this utterance the use of the word "will" indicate what follow is facts.

\section{d. Non-factive Presupposition}

Utterance: "How dare you pretend that this can be solved with just business as usual and some technical solutions? With today's emissions levels, that remaining CO2 budget will be entirely gone within less than eight and a half years."

According to Yule's theory, the presence of verb "pretend indicates that what the speaker said is considerably assumed to have followed by an untrue information. In this utterance means someone is lying that the problem already solved.

\section{e. Lexical Presupposition}

Utterance: "We are in the beginning of a mass extinction and all you can talk about is money and fairytales of eternal economic growth. How dare you!"

This sentence is categorized in to lexical presupposition, triggered by the word "beginning", when someone uttered this sentence means that the event hasn't happened before.

Utterance: "You are failing us, but the young people are starting to understand your betrayal."

In the datum above, based on theory by Yule, the use of word "starting" was categorized as lexical items which triggers lexical presupposition.

\section{Entailment}

\section{a. One-way Entailment}

Utterance: "The popular idea of cutting our emissions in half in 10 years only gives us a 50\% chance of staying below 1.5 degrees [Celsius] and the risk of setting of irreversible chain reactions beyond human control."

In the utterance above, firstly Greta states that the popular idea of cutting the emission in half in 10 years. In order to expressing disapproval, she strengthens her statement by adding two additional sentences. By stating that those popular idea only give $50 \%$ chance of staying below 1.5 degree [Celsius], and she also mention the risk is beyond human control. One of the distinctive characteristics of one way entailment is the speaker giving more details to make the audience trust the argument. By providing the two sentences that explain the reason why she is not agree with cutting the emissions make the audiences believes in her.

Utterance: "To have a $67 \%$ chance of staying below a 1.5 degrees global temperature rise. The best odds given by the [Intergovernmental Panel on Climate Change], the 
world had 420 gigatons of CO2 left to emit back on Jan. 1st, 2018. Today, that figure is already down to less than 350 gigabytes."

In the utterance above, Thunberg argues that there is $67 \%$ of chances to stay below 1.5 degrees global temperature rise. Then she gives more detailed facts given by Intergovernmental Panel on Climate Change that the $\mathrm{CO} 2$ left is 420 gigatons to emit back. She also straightens her argument by giving detailing date which is Jan 1st, 2018. The way she delivers this one-way entailment is by exploring some facts about the idea mentioned by the speaker. When she utters her statement, she explains more by giving further fact. She wants the audience or listener to believe in her. The strategy of giving facts or examples is also employed by Greta Thunberg.

\section{b. Two-way Entailment}

Utterance: "You say you hear us and that you understand the urgency. But no matter how sad and angry I am, I do not want to believe that. Because if you really understood the situation and still kept on failing to act, then you would be evil. And that I refuse to believe"

In the utterance above, the words used in the two sentences has same the meaning. However, a word in the first sentence is replaced by another word. In datum above, the sentence "I do not want to believe that" in the first sentence is replaced by "I refuse to believe" in the second sentence. But the meanings of those two sentences are the same. Thus, the first sentence is the paraphrase of the second sentence.

Utterance: "People are suffering. People are dying. Entire ecosystems are collapsing."

In the utterance above, the word "suffering" in the first sentence is replaced by "dying" in the second sentence. The main ideas of those two sentences are similar. When the speaker says that people are suffering. In other words, the speaker also means that people are dying. In conclusion, two-way entailment can be seen in two sentences or more that have the same meaning. They are an idea that is uttered repeatedly. However, those sentences are used with a different expression. The speaker's aim in using twoway entailment is to emphasize the idea of the sentence to the listener or audience.

\section{Language Function}

Utterance: "The popular idea of cutting our emissions in half in 10 years only gives us a 50 percent chance of staying below 1.5 degrees and the risk of setting off irreversible chain reactions beyond human control."

It can be seen in utterance above, that the presupposition used in datum above is existential presupposition. From those utterance it can be analyzed that there is a popular idea to solving the global warming problem. And the entailment that used in datum above is one-way entailment, which the speaker adding more details about her argument. Based on Jakobson's language function theory, it can be categorized the function of Greta's utterance is referential function. The referential function is related to the factor of context and describes the situation, object or mental state. In this utterance it can be seen that Greta persuade the audience that the popular idea of cutting the emission is does not have the effect that world leaders proclaim, by stating the fact and mentioning the risk. 
Utterance: "We will not let you get away with this. Right here, right now is where we draw the line. The world is waking up and change is coming, whether you like it or not."

It can be seen from the utterance above, that the presupposition used in datum above is existential presupposition, and the entailment used is one-way entailment. From those utterance it can be analyzed that the world is exist and it is changing. Based on Jakobson, emotive function focuses on the speaker and aims at a direct expression of the speaker's attitude toward what she is speaking about. In the end of her speech, Greta expresses her feeling by saying this utterance. She wants the audience to know that the world is changing.

\section{DISCUSSION}

\section{Presupposition}

From the finding, it was found that the dominant type of presupposition used in Greta Thunberg's speech is existential presupposition (56.25\%). This case happens because the speaker or Greta use existential presupposition to emphasizes, drawing attention and sympathy whether from her generation nor the audiences.

Meanwhile, the less frequent presupposition that appears in the speech is nonfactive presupposition. It happens because the number of this presupposition is less than other presupposition, it only appears once throughout the speech. Because nonfactive presupposition delivers falsity of a case while the speech of Greta Thunberg mostly contain about facts which makes non-factive presupposition inappropriate to use.

Each presupposition has specific function in the speech. The first is existential presupposition, this type of presupposition triggered by the use of definite noun phrase. Based on the data, the speaker mentioned seven definite noun phrase. Such as, young people, people, the science, the politics, the popular idea, the aspects of equity, the consequences and the eyes. The use of this definite noun phrase is to show the listener that young people, people, the science, the politics, the popular idea, the aspects of equity, the consequences and the eyes are exist.

Besides triggered by definite noun phrase, existential presupposition also triggered by the use of possessive contraction in this speech such as my which refers to the speaker herself, our which refers to the speaker and the audience, your which refers to the world leader The speaker mostly use this type of presupposition to deliver their intentions, and convincing the audience.

The second is counterfactual presupposition the use of this presupposition to show the truth implicitly by uttering the contrary condition. Based on Yule (1996) theory, counterfactual presupposition triggered by the use of IF-clauses.

In the data, this presupposition appears twice throughout the speech. The first sentence is "This is all wrong. I shouldn't be up here. I should be back in school on the other side of the ocean", contrary to the facts that she is attending the summit. The second sentence "If you really understood the situation and still kept on failing to act then you would be evil and that I refuse to believe". This is contrary to the fact that the world leader does not understanding the situation.

The third is factive presupposition which aims to declaring the fact. In this speech, the speaker mostly apply this type of presupposition to tell the audience about facts, when she applying this presupposition she used data which has reliable source. 
This type of presupposition appears twice in the speech. Firstly, "To have a 67 percent chance of staying below 1,5 degree global temperature rise - the best odds given by the IPCC (Intergovernmental Panel on Climate Change). The world had 420 gigatons of CO2 left to emit back on January 1st 2018. Today, that figure is already down to less than 350 gigabytes", triggered by the use of word odds means what follows is the fact, in the sentence above the speaker mentioned reliable source IPCC (Intergovernmental Panel on Climate Change) after the words odds. Means that, according to IPCC or Intergovernmental Panel on Climate Change the world had 420 gigatons of CO2 left to emit back on January 1st 2018. Secondly, "There will not be any solutions or plans presented in line with these figures here today, because these numbers are too uncomfortable and you are still not mature enough to tell it like it is". Triggered by the use of word "will" makes this sentence categorized as factive presupposition. Means that there is no solution and plans presented today.

The fourth is non-factive presupposition which is used to show the falsity of something, based on the data this type of presupposition applied by the speaker to criticize something or to say her disagreement about something. In the speech, this presupposition only appears once. In the sentence, "How dare you pretend that this can be solved with just business as usual and some technical solutions? With today's emissions levels, that remaining $\mathrm{CO} 2$ budget will be entirely gone within less than eight and a half years". Triggered by the use of word "pretend", which means what follows is not true. In the sentence above means, the world leader pretending or lying that the problem can be solved with business and technical solutions which it's impossible with today's emissions level.

The fifth is lexical presupposition, based on the data the speaker use this type of presupposition to deliver reminder to the audience. Appears twice in the speech, the first sentence is "We are in the beginning of a mass extinction and all you can talk about is money and fairytales of eternal economic growth. How dare you!'. triggered by the word "beginning". In the sentence above means, we are now in the beginning of mass extinction which never happen before, but the world leader only cares about money and economic growth. In the second sentence, "You are failing us, but the young people are starting to understand your betrayal." Triggered by the use of word "starting". The sentence means, young people are start to realizing the betrayal done by the world leader.

In conclusion, from six types of presupposition, there are five types of presupposition used in Greta Thunberg's speech. Which is existential presupposition, counterfactual presupposition, factive presupposition, non-factive presupposition, and lexical presupposition.

\section{Entailment}

The finding show that all types of entailment were employed by Greta Thunberg in her speech at UN Climate Summit 2019. They are one way entailment and two-way entailment. One-way entailment is the most used in Greta Thunberg's Speech. This entailment appears for nine times throughout the speech. The one-way entailment is the most common used entailment in delivering ideas. They usually give details of the main idea, the details can be in the form of example, explanation, or description. The use of one way entailment is to help the hearer to understand the idea. An example of one way entailment is in the following datum. 
"To have a 67 percent chance of staying below 1,5 degree global temperature rise. The best odds given by the IPCC (Intergovernmental Panel on Climate Change). The world had 420 gigatons of $\mathrm{CO} 2$ left to emit back on January 1st 2018. Today, that figure is already down to less than 350 gigabytes."

In the utterance above, Greta states her arguments the best chance to stay below 1.5 degree on global temperature rise. Then, she gives some details with reliable source on how to get 67 percent chance. Based on IPCC (Intergovernmental Panel on Climate Change) the world must emit back 420 gigatons on January 1st 2018, the good news is those number are down to 350 gigabytes today. Therefore, that sentence is categorized as one way entailment.

The other way to deliver one way entailment, except giving some details is by giving some explanation about the idea mentioned by the speaker. When a speaker utters a statement, and explains it more, means that they want the audience or hearer believe in them. The strategy of giving example is also employed by Greta.

"Fifty percent may be acceptable to you. But those numbers do not include tipping points, most feedback loops, additional warming hidden by toxic air pollution or the aspects of equity and climate justice"

In the utterance above, Greta firstly states that fifty percent is enough according to the world leader. Then, she strengthens her statement by giving explanation why she explains why those fifty percent is not acceptable in the second sentence. By stating that those fifty percent do not include tipping points, most feedback loops, toxic air pollution, the aspects of equity and climate justice. By providing further explanation, Greta makes the audience or hearer believe in her statement.

Another example of one-way entailment is presented below.

"So a 50 percent risk is simply not acceptable to us. We who have to live with the consequences."

In the datum above, Greta argues that fifty percent risk is not acceptable to us. Then, in the second sentence she explains who is "us" that she mentioned. Us here means we who bear all the consequences.

Secondly, Two-way entailment appeared twice in Greta Thunberg's speech. The two-way entailment can be identified if the paraphrase is happening. The easiest way to paraphrase is rewording means replacing a word by another word which has the same meaning. The two-way entailment intended to emphasizes the important point so that listeners understand and remember that this is an important point. This phenomenon also happened in Greta's utterance in her speech.

\section{"People are SUFFERING. People are DYING. Entire ecosystems are COLLAPSING."}

Those three sentences are in relation of two-way entailment. The words used in those sentences are almost the same. The word 'suffering' in the first sentence is replaced by the word 'dying' in the second sentence, and the word 'dying' is replacing by the word 'collapsing' in the third sentence. Therefore, those three sentences have 
similar meaning. When a speaker uses such way of delivering idea, means they want the audience or hearer really get what they want to deliver.

"You say you hear us and that you understand the urgency, but no matter how sad and angry I am, I do not want to believe that. Because if you really understood the situation and still kept on failing to act, then you would be evil. And that I refuse to believe."

In utterance above, those two sentences are in relation of paraphrase. The main idea of the two sentences is similar. When the speaker says that she does not want to believe that they understand the urgency, in other word she also said if they really understand the situation.

In conclusion, in expressing one way entailment a speaker has many choices of methods such as, giving example, description or giving conclusion of the idea that the speaker wants to deliver. One way entailment is expressed by the speaker to strengthen their idea. Meanwhile, two-way entailment can be seen in two or more sentence that has similar or exact same meaning. The speaker's aim in using two-way entailment is to emphasize the idea of the sentence.

\section{The Contribution of Presupposition and Entailment in Topic of the Speech}

In this research giving knowledge about how presupposition and entailment contribute to the topic of the speech by analysing the types of presupposition and entailment that was found in the speech.

In the datum 16 "There will not be any solutions or plans presented in line with these figures here today, because these numbers are too uncomfortable and you are still not mature enough to tell it like it is."

This datum hangs on presupposition that the solutions and plans are not presented today and on what is entailed by this. The first line of the datum presents the assertion "There will not be any solutions and plans today". "will be not" means that nothing happens. In other words, the narrator explicit words constitute an assertion about the truth value of the proposition "the solution and plans" are not presented today; her words assert not that it is true or false, but according to the speaker there is no solution or plans presented today. So, the propositions are:

a. The solution and plans are not presented today.

b. The solution and plans are not available.

If proposition (b) is not true, then proposition (a) is also not true. That is, if the solution and plans are presented today, it makes no sense to say to say The solution and plans are not presented today is true or false. So, the speaker assumption is the solution and plans are not available because it is not presented today. The type of presupposition in this utterance is existential presupposition, because the noun used in Greta's utterance is a definite noun phrase "The solution and plans" which according to Yule (1996), existential presupposition are generally exist in any definite noun phrase

Based on theory by Stalnaker $(1970,1973,1974,1978)$ presupposition are generally seen as imposing requirements on the possible context of utterance. Based on the idea of contexts of utterance in terms of the common ground - the set of worlds which compatible and mutually supposed for purpose communication. Assertation 
used to add information to the common ground. The common ground for this utterance is "the solution and plans" And what exactly is entailed by "the solution and plans."

The very specific details of these "solution and plans" in order to solve global warming problem are given by Greta Thunberg's. One of the solution mentioned by Greta's is she urges everyone to use their right to vote and pick a candidate that is going to put climate change as main problem and continually press those in power to adapt their policies and adopt new legislature to solve climate change problem and save the earth.

Thus, the proposition (a) The solutions and plans are presented today entails proposition (b) The solutions and plans are adapting their policies and adopt new legislature that consider climate change as a major problem. Because the truth of (a) ensures the truth of (b) and the falsity of (b) ensures the falsity of (a). In other words, if it is true that the solution and plans are presented today, it is necessarily true that the policymakers are consider climate change as a major problem in their polices and legislature. And if it is not true the policymakers are considered climate change as major problem in their policies and legislature, then it is necessarily not true that the solutions and plans are presented.

The presuppositions of Greta's must be entailed by the global context or common ground knowledge that precedes the conversation. It means that the global context or common ground knowledge entails that presupposition. In example above, the common ground for "the solution and plans" are she urges everyone to use their right to vote and pick a candidate that is going to put climate change as main problem and continually press those people to adapt their policies and adopt new legislature to solve climate change problem.

From the utterance above, the utterance is categorized as referential function because the utterance are containing important information to be known by the audience. Here, Greta's shows that she wanted to make her audience know about these solution and plans. In this utterance, Greta Thunberg, as the speaker wants to deliver her thoughts to the audience about the solution of global warming.

All of the utterance which categorized as one-way entailment are mostly categorized as referential function. Because one of the characteristics of one-way entailment is commonly used by people in delivering their ideas by giving more details of the main idea. And the detail can be in the form of explanation, example or description. Meanwhile, the referential function is the function that contains an information message about the speaker's thought which be delivered to the audience. It means that Greta Thunberg focuses on her audience through the message that she delivered in this speech. By adding further details of her argument, she wants to make the audience to focuses on the theme of the speech, which is global warming. Through this speech, she wants to persuade and convince the audience to believe in her argument about global warming. 


\section{CONCLUSION AND SUGGESTION}

\section{Conclusion}

Based on the data analysis result and discussions in the previous chapter, several points can be concluded. Firstly, that several presuppositions can be found in Greta Thunberg's speech at UN Climate Action Summit 2019. From six types of presupposition based on Yule (1996:26) it was found there are five types of presupposition in Greta Thunberg's speech, which are existential presupposition, counter-factual presupposition, factive presupposition, non-factive presupposition, lexical presupposition. Mostly she used existential presupposition in her speech which appear nine times $(56.25 \%)$, in which those existential presuppositions have the function to emphasizes, drawing attention and sympathy toward the listeners.

Secondly, she also used counter-factual presupposition to give the idea about the ideal world and to deliver sarcasm toward the attendee. The counter-factual presupposition appears 2 times $(12.5 \%)$ throughout the speech. Thirdly, she used factive presupposition to stating the fact to straighten her argument. The factive presupposition appears twice $(12.5 \%)$ in the speech. Fourth, she used a non-factive presupposition to emphasize her speech. The non-factive presupposition appears one time $(6.25 \%)$ in the whole speech. Finally, she used a lexical presupposition to emphasize and intimidate the attendee. The lexical presupposition appears twice $(12.5 \%)$ in her speech. Basically, these results bring the ideas conveyed by Lisetyo (2020) that the meaning of those presupposition is basically based on what the theory said. For example, the meaning of existential is to show something to be existed, the meaning of lexical is based on the word contextual meaning used in the utterance, the meaning of structural is based on the use of W-H question words, and the meaning of factive is based on the word and verb that means a fact, while the meaning of of nonfactive is the contrary of factive.

Thus, those presuppositions have a contribution by making her speech more attractive, mesmerizing, interesting, persuasive, and effective to both attendee and the listener. To have a deeper understanding of the speech, the research also analyzed by the entailment theory.

Based on theory by Yule (1998:129) entailment is something that follows from what is mentioned before. Entailment can be divided into several types, some scholar have their own types of entailment. The one that is used in this research is by Griffiths (2006) who divides entailment into two, the first one is one-way entailment and the second one is two-way entailment. The most common entailment used in this speech is one-way entailment. One-way entailments appears 11 times $(87.5 \%)$ or almost the whole of the speech use this type of entailment. This type of entailment is commonly used to delivering the ideas through the utterance. The speaker usually adding some more details of the main idea. The details can be in the form of description, example, or explanation. It means to help the listener understand the idea.

Lastly, two-way entailment appears two times $(12.5 \%)$ in the speech. Twoway entailment can be seen in two or more sentences that have the same meaning. They have the same idea but the speaker used a different expression to emphasize the idea.

Then to find the connection between the presupposition and entailment used in the speech, the research also done by using dynamic approach theory. Based on theory by Stalnaker $(1970,1973,1974,1978)$, The presuppositions of the speech must be entailed by the global context or common ground knowledge that precedes the 
conversation. It means that the global context or common ground knowledge entails that presupposition.

In order to find the contribution of presupposition and entailment in the context of the speech. The research also done by using language function theory by Roman Jakobson (1960). From five types of language function, three was found in this speech which are, referential function, emotive function, and conative function.

Because the speaker mostly used one-way entailment which has characteristic for adding some more details of the main idea, which lead to the use of referential function. Which can be seen by the dominant of the use of referential function in this speech. Referential function is a function to convey information it can be seen through different forms of speech such as interrogative or declarative speech. And this function aims to send information or the speaker idea to the audience.

\section{Suggestion}

In this section, the researcher suggests for future researchers who want to write this kind of research to widely extend the research by enhancing the research focus not only exploring the types of presupposition and entailment but also use more varieties in pragmatics approach such as language function or dynamic which used in this research. The research about the dynamic between presupposition, entailment, and language function is still lacking, and it is important to acknowledge the dynamic phenomenon of those three. Therefore, it is a good chance for the other researcher to do further research in order to widen the research about pragmatic. The research of presupposition, entailment and language function hopes to contribute to the composition as well as a better understanding of speeches.

\section{REFERENCES}

Ariyanti, L., \& Nistiti, N. U. (2019). Presupposition in Feminist Speech. 380. Proceedings of the Social Sciences, Humanities and Education Conference (SoSHEC 2019). 161-165. https://www.atlantis-press.com/proceedings/soshec$19 / 125926103$

Ariyanti, L., Adam Damanhuri, Mamik Tri Wedawati, \& Much. Khoiri. (2020). Presupposition Used by the Student and the Lecturer. Proceeding of International Joint Conference on Arts and Humanities (IJCAH 2020). https://www.atlantispress.com/proceedings/ijcah-20/125947338

Brinton, Laurel J. 2000. The Structure of Modern English: A Linguistic Introduction. Amsterdam: John Benjamins Publishing Company.

Catur, I. \& Ariyanti, L. (2016). Revealing The Function Of Reference In Presupposition Of English Cigarette Taglines In Djarum And Its Sub-Brands Advertisements. 04, 26-35. https://jurnalmahasiswa.unesa.ac.id/index.php /language-horizon/article/view/16173

Fromkin, Victoria, Robert Rodman, and Nina Hyams. 2003. An Introduction to Language. 7th Edition. Boston: Thomson Wadsworth.

Griffiths, Patrick. 2006. An Introduction to English Semantics and Pragmatics. Edinburgh: Edinburgh University Press Ltd. 
Holmes, J. (2013). An introduction to sociolinguistics (4th ed.). London and New York: Routledge Taylor and Francis Group.

Jakobson, R. (1995). On Language. Cambridge: Harvard University Press.

Kreidler, Charles W. 1998. Introducing English Semantics. London: Routledge.

Levinson, Stephen C. 1983. Pragmatics. New York : Oxford University Press.

Miles, Matthew B., Michael Huberman, and Johnny Saldana. Qualitative Data Analysis. 3rd ed. California; Sage Publication, 2014. Print.

Rachmawati, Ida Catur Wahyu (2016). Revealing The Function of Reference in Presupposition of English Taglines in Djarum and It's Sub-Brand Advertisements. Surabaya: State University of Surabaya.

Richardson, J. E. (2007). Analyzing newspapers: An approach from critical discourse analysis. NY: Palgrave, Macmilan.

Rambaud, Margarita G. 2012. Basic Semantics. Madrid: Editorial UNED.

Suwarni, Erni. (2017). Revealing Miranda Priestly's Power Through Her Presupposition in the Devil Wears Prada Movie. SKRIPSI. Universitas Negeri Surabaya: Surabaya.

Yule, George. (1996). Pragmatics. Oxford : Oxford University Press. 